\title{
Zeolite-X Encapsulated Ni(II) and Co(II) Complexes with 2,6-Pyridine Dicarboxylic Acid as Catalysts for Oxidative Degradation of Atenolol in an Aqueous Solution
}

\section{Fatemeh Hassani}

Islamic Azad University

Mahboubeh A. Sharif ( $D$ mahboubeh.sharif@yahoo.com )

Islamic Azad University https://orcid.org/0000-0003-0200-8404

Masoumeh Tabatabaee

Islamic Azad University

Mahboobeh Mahmoodi

Islamic Azad University

\section{Research Article}

Keywords: Zeolite-X, Nano porosity, lon-exchange, Degradation of atenolol, Dipicolinic acid

Posted Date: December 29th, 2021

DOI: https://doi.org/10.21203/rs.3.rs-1200430/v1

License: (c) (i) This work is licensed under a Creative Commons Attribution 4.0 International License.

Read Full License 


\section{Abstract}

Complexes of Co (II) and Ni (II) with dipicolinic acid, 2,6-pyridine dicarboxylic acid $\left(\mathrm{PydcH}_{2}\right)$ have been synthesized in the $\mathrm{NaX}$ (zeolite-X) nanopores. The formation of zeolite X encapsulated $\mathrm{Co}(\mathrm{II})$ and $\mathrm{Ni}(\mathrm{II})$ complexes ([M(pydcH) $\left.)_{2}\right]-\mathrm{NaX}$, where $\mathrm{M}=\mathrm{Co}(\mathrm{II})$ and $\left.\mathrm{Ni}(\mathrm{II}]\right)$ were confirmed using spectroscopic methods of FT-IR, elemental analysis, XRD, FE-SEM, and TEM. It was affirmed that the encapsulation of complexes in $\mathrm{NaX}$ pores was performed without changes in the structure and shape of the zeolite. The oxidative degradation reaction of atenolol with hydrogen peroxide as an oxidant was performed in the presence of synthesized $\left[\mathrm{M}(\mathrm{pydcH})_{2}\right]-\mathrm{NaX}$ nanocomposites to study their catalytic activity. Therefore, oxidation of atenolol was performed under different conditions of catalyst, temperature, and time. Under optimal conditions, catalysts $\left[\mathrm{Co}(\mathrm{pydcH})_{2}\right]-\mathrm{NaX}$ and $\left[\mathrm{Ni}(\mathrm{pydcH})_{2}\right]-\mathrm{NaX}$ showed $82.3 \%$ and $71.1 \%$ activity of atenolol oxidation, respectively. These catalysts were stable after recovery and were used three more times. The results showed that these catalysts were reusable and had a reduction in the catalytic activity of less than ten percent.

\section{Introduction}

Today, the pharmaceutical and health industries have caused the entry of various pollutants into the environment and water resources, and as a result, threaten the health of the people. Therefore, removing them from the environment becomes more important [1-4]. Typically, drugs either absorb activated sludge and enter the sludge digesters and can play a role in inhibiting the biodegradation activity of anaerobic bacteria, or by entering conventional wastewater treatment processes with effluent, entering soil or surface water, groundwater and They are drunk [5-7]. Medicinal compounds, including cardiovascular drugs, are substances that are very useful and despite their side effects, they are widely used in medicine [8-11]. Among these drugs is one of the most widely used cardiovascular drugs called atenolol, which is one of the most widely used drugs due to the prevalence of cardiovascular disease and hypertension. Atenolol is a beta-blocker and is used to treat chronic angina, hypertension, high blood pressure (alone or with other antihypertensive drugs) and to prevent myocardial infarction [12]. About 50 to $60 \%$ of the drug is absorbed from the gastrointestinal tract. The drug is low protein-bonded in plasma, the drug is metabolized in small amounts in the liver, the biological half-life of the drug is 6-7 hours and the time required to reach the peak effect is $2-4$ hours, 85 to $100 \%$ of the drug is unchanged by the kidney It is predicted that large amounts of this compound will be present in household, hospital, pharmaceutical and groundwater sources [13-15] Therefore, it is necessary to provide a simple, sensitive, and fast method to remove drugs from aqueous sources [16-18]. Many methods are used to remove these compounds, including membrane processes such as nanofiltration, ultrafiltration, reverse osmosis, etc., that their disadvantages are high pressure, high cost of the membrane, and most importantly chemical or microbial clogging of the membrane that prevents water from passing through the filter and reducing the flow [19]. Conventional oxidation treatment is another method of removing contaminants by adding an oxidizing agent to a solution containing contaminants. With this oxidation, some of the contaminants are removed and decomposed. In wastewater treatment, oxidizers such as chlorine and other chlorine- 
containing compounds (such as hypochlorous acid), oxygen, ozone, and hydrogen peroxide are used for oxidation. Chlorine and its derivatives can be used in the role of chemical oxidant in wastewater treatment. However, due to its high oxidation strength, it reacts with aromatic rings and double bond substances, which result in halogenated organic matter, and some of them have the potential for carcinogenic risk. Therefore, the use of chlorine in the decomposition of wastewater organic matter is not appropriate [20,21], So catalytic oxidation with $\mathrm{H} 2 \mathrm{O} 2$ in the presence of an appropriate catalyst is considered.

Transition metal complexes of transfer elements are good catalysts and some of them have high solubility in solution, so they are considered homogeneous catalysts [22, 23]. Although homogeneous catalysts have high activity and selectivity, but the difficulty of separating them from the product limits their industrial applications. And this problem can be solved by heterogeneizing them [24-26]. Homogeneous catalysts can be converted to heterogeneous catalysts by bonding or encapsulation [27, 28].

Zeolites are crystalline aluminosilicates with cavities and channels of the specified size and unique properties such as ion exchange, adsorption, and catalytic activity which are very suitable in industrial applications. [29]. The general oxide formula for $\mathrm{NaX}$ zeolite is $\mathrm{Na}_{2} \mathrm{O}_{2} \mathrm{Al}_{2} \mathrm{O}_{3} \cdot 5 \mathrm{SiO}_{2}$ and for its unit cell is $\left(\mathrm{Na}_{88} \mathrm{Al}_{88} \mathrm{Si}_{104} \mathrm{O}_{384} \cdot 172.1 \mathrm{H}_{2} \mathrm{O}\right)$. The NaX zeolite is of the Fujasite family and the sodalite cages are connected by the secondary prismatic units with a hexagonal base. The size of the cavity and its channels is about $0.74 \mathrm{~nm}$ (relatively large), and it is used as a stable size in the production of catalysts [30].

To increase the catalytic activity of the complexes, they can be encapsulated in the pores and cavities of the inorganic polymer structure [31]. Zeolites are unique among all types of compounds with porous and porous structures, because they have a regular crystal structure with high chemical and thermal stability. The proper structure of zeolites has made them a suitable environment for trapping active metal complexes and metal clusters, which use these modified systems as catalysts [32]. There are three methods for encapsulating coordination compounds in the pores and channels of zeolite, including the method and synthesis of zeolite complexation, the template synthesis method and the synthesis method, and the flexible ligand method, simultaneously $[33,34]$. In this research work, the flexible ligand method has been used. First, the appropriate metal enters the zeolite structure by ion exchange method, and then the appropriate ligand in terms of size and flexibility is spread in the zeolite structure, in this method. The ligand used in this method must have sufficient flexibility to be stable and not be degraded during adsorption and binding to the exchanged metal in the zeolite pores. The amount of complex produced in the zeolite pores is proportional to the amount of cation exchanged with the sodium cations in the zeolite structure. The excess amount of ligand and metal complex on the outer surface of the zeolite should be separated by a solvent.

Continuing the previous work [i], we describe the synthesis and characterization of the encapsulated $\mathrm{Ni}$ (II) and $\mathrm{Co}$ (II) complexes of pydcH $\mathrm{H}_{2}$ in zeolite-X and their use in the oxidation of atenolol (an organic 
pollutant in wastewater) with hydrogen peroxide as an oxidant.

\section{Experimental}

\subsection{Materials and Physical methods of analysis}

All materials required for the synthesis of compounds were purchased commercially from Sigma Aldrich or Merck. The FT-IR spectra of the synthesized solids were recorded with $\mathrm{KBr}$ tablets in the range of 4000 $400 \mathrm{~cm}^{-1}$ by a Bruker Tensor 27 FT-IR-spectrophotometer. The TESCAN, Mira 3-XMU field-emission scanning electron microscope (FE-SEM) and transmission electron microscopy (TEM) (Zeiss-EM10C$80 \mathrm{KV}$ ) were used to examine the morphology of the samples and particle shape, respectively. To study the structure and phase detection in the synthesized samples, X-ray diffraction (XRD) was used and it was applied to the surface of the sample by CuKa on a Philips, X'Pert PRO. Perkin-Elmer Optima 2000 DV ICP-AES was used for elemental analysis of samples. The UV-Vis spectra were recorded in the range of 200-700 nm using the Avantes spectrophotometer (AvaSpec-ULS2048LTEC).

\subsection{Catalyst preparation 2.2.1 Preparation of zeolite-X}

Synthesized zeolite-X was used as a substrate in the laboratory [35]. Sodium silicate and sodium aluminate were used as raw materials in the preparation of zeolite $X$. To prepare sodium silicate, a mixture of silica gel $(3 \mathrm{~g})$, sodium hydroxide $(2.4 \mathrm{~g})$, and deionized water $(6 \mathrm{ml})$ was stirred to give a clear solution. Sodium aluminate solution was obtained by mixing aluminum isopropoxide $(6.9 \mathrm{~g})$, sodium hydroxide $(2.4 \mathrm{~g})$, and deionized water $(9 \mathrm{ml})$ in another beaker. Stirring was continued for about ten minutes (below $80^{\circ} \mathrm{C}$ ) until the material was completely dissolved and a clear solution was obtained. Evaporation of water was prevented by placing the watch glass on the beaker. After both solutions reached room temperature, the aluminum silicate solution was added to the sodium silicate solution. Then $27 \mathrm{ml}$ of water was added and the reaction mixture was stirred to form a perfectly homogeneous mixture. The mixture was immediately transferred to a polypropylene container with a screw cap and placed in an oven at $90^{\circ} \mathrm{C}$ for 3-4 hours. The reaction mixture was then cooled to room temperature. After sediment settling, the mixture was filtered and washed with plenty of water. Washing was done several times, but no smoothing method was used to wash away the residue. Finally, the white zeolite $X$ crystals were dried in an oven or at room temperature.

\subsubsection{Preparation of $\left.\left[\mathrm{M}(\mathrm{pydcH})_{2}\right)\right]-\mathrm{NaX}(\mathrm{M}=\mathrm{Ni}$ and $\mathrm{Co})$}

Zeolite X was used to synthesize nanocomposite catalysts through encapsulating nickel (II) and cobalt (II) complexes in zeolite pores. In this regard, the flexible ligand method was used in the following two steps.

\subsubsection{Preparation of $\mathrm{M}(\mathrm{II})-\mathrm{NaX}$}


The exchanged M(II) zeolite-X (M(II)-NaX) was prepared according to the method described in the literature [36]. Zeolite X (4 g) was transferred to a $250 \mathrm{ml}$ balloon together with deionized water (250 $\mathrm{ml})$ and $4 \mathrm{mmol} \mathrm{M}\left(\mathrm{NO}_{3}\right)_{2}$. The suspension was refluxed for 24 hours at $90^{\circ} \mathrm{C}$. Then, the mixture was filtered and the precipitate was washed several times with deionized hot water. The precipitate was placed in an oven for 15 hours at $150^{\circ} \mathrm{C}$ to dry completely.

\subsubsection{Preparation of Encapsulated M(II) Complex in $\mathrm{NaX}$}

The dry precipitate $(1 \mathrm{~g})$ obtained from the before step was placed in a $250 \mathrm{ml}$ balloon and placed in an oil bath. $12 \mathrm{mmol}$ of pyridine 2 and $6 \mathrm{~d}$-carboxylic acid ligand and $100 \mathrm{ml}$ of ethanol were added to the precipitate and refluxed for $24 \mathrm{~h}$ at $90^{\circ} \mathrm{C}$. Then the mixture was placed in a smooth oven at $150^{\circ} \mathrm{C}$ to dry completely. To remove unreacted ligands, the precipitate was soaked with ethanol and acetonitrile for 6 hours, respectively. After drying, the resulting mixture was placed in a solution of sodium chloride $(100 \mathrm{ml}$, $0.01 \mathrm{M}$ ) for $24 \mathrm{~h}$ (for the removal of uncoordinated metal ions from the zeolite cavities). After filtering the reaction mixture and washing the precipitate with deionized water several times, it was dried at $120^{\circ} \mathrm{C}$.

\subsection{Catalytic Reaction for the Oxidation of Atenolol}

An aqueous solution of atenolol ( $10 \mathrm{~mL}, 2 \mathrm{ppm})$, was prepared and its absorption was measured in the range of $250-700 \mathrm{~nm}$ by spectrophotometer. Then different amounts of catalyst $(0.005,0.01$, and 0.015

g) and hydrogen peroxide $(0.01,0.02$, and $0.03 \mathrm{ml}, 30 \mathrm{wt} . \%$, as an oxidant) were added to the solution and were stirred at ambient temperature $\left(30^{\circ} \mathrm{C}\right)$ for 30,60 and 180 minutes. The mixture was centrifuged and the adsorption of clear solution was measured in the range of $250-700 \mathrm{~nm}$. To recover the catalyst, the residue was filtrated and washed with solvents for reuse.

\section{Results And Discussion}

Both the $\mathrm{Co}(\mathrm{II})$ and $\mathrm{Ni}(\mathrm{II})$ ions coordinated with pydc were encapsulated in the pores of zeolite $\mathrm{X}$ by the Flexible Ligand Method [36]. First, $\mathrm{Na}^{+}$ion was exchanged with $\mathrm{M}(\mathrm{II})$ ion and then the complex formation was performed in M (II) - X zeolite cavities by adding an additional amount of the $\mathrm{pydcH}_{2}$ as ligand. The pydcH $\mathrm{H}_{2}$ can diffuse simply via the zeolite pores because of its flexible nature and then the complexes of $\left[\mathrm{M}(\mathrm{pydcH})_{2}\right]$ were formed in the zeolite pores. So, the prepared complex inside the cages of zeolite is too large to come out of the pores. To remove excess of the ligand inside the pores as well as located on the surface of zeolite the precipitate was Soxhleted in ethanol and acetonitrile for $6 \mathrm{~h}$, respectively.

\subsection{Characterization of $\left.\left[\mathrm{M}(\mathrm{pydcH})_{2}\right)\right]-\mathrm{NaX}$}

\subsubsection{FT-IR spectroscopy}

The FT-IR spectra of $\mathrm{NaX}$ and encapsulated $\mathrm{Co}(\mathrm{II})$ and $\mathrm{Ni}(\mathrm{II})$ complexes (catalysts) are shown in Figure 1. The study of FT-IR spectra of different zeolites shows the presence of two groups of vibrating bands in these compounds. The first group is bands that are related to the internal vibrations of the tetrahedral 
$\mathrm{TO}_{4}(\mathrm{~T}=\mathrm{Al}, \mathrm{Si})$. These bands are not sensitive to the overall structure of the zeolite and are often seen in all zeolite structures. The second group of bands is found only in some zeolite structures and is therefore attributed to the connections between the tetrahedral anions. Due to the destruction of the zeolite structure, the intensity of this group of bands is reduced or disappears completely [37]. The bands around $3450 \mathrm{~cm}^{-1}$ (broad) and $1642 \mathrm{~cm}^{-1}$ have related to the stretching and bending modes of water molecules adsorbed by the zeolite $X$, respectively [35]. The band appearing at $1010 \mathrm{~cm}^{-1}$ is also attributed to the quadrilateral Si-O-Al tensile vibration. Symmetric T-O-T stretching, six-membered rings of T-O-T symmetric stretching, and Si-O-Si symmetric stretching are assigned by absorption bands at 764, 582, and $657 \mathrm{~cm}^{-1}$, respectively. Also, the symmetric bending of the modes of T-O is assigned by the band at $480 \mathrm{~cm}^{-1}$. These findings are similar to previous studies and this proves the formation of zeolite $X$ in this work [38, 39].

IR spectroscopy also provides good information about encapsulated metal complexes and the crystal structure of the host zeolite. In the spectrum of both samples, the absorption bands are affected by the crystal structure of the zeolite [40]. In the range of $3700-3300 \mathrm{~cm}^{-1}$, vibrations related to hydroxyl groups can be detected (corresponding to the connections of the $\mathrm{OH}$ group of ligands). The fact that the main vibrations in the structure of the zeolite have not changed or significantly expanded can be confirmed that the process of encapsulation of the complexes has not changed the framework of the zeolite. The relevant bands are weakened in composites, due to the low concentration of complexes, and therefore it is observed only in areas such as $1800-1500 \mathrm{~cm}^{-1}$ (related to the carboxylate groups [41]) that the zeolite matrix does not have an absorption band. Adsorption bands of nickel (II) and cobalt (II) complexes encapsulated in zeolite are shifted to lower frequencies compared to the free compounds.

\subsubsection{Analytical data}

The analytical data of $\mathrm{NaX}, \mathrm{M}$ (II)- $\mathrm{NaX}$, and ([M(pydcH) $\left.)_{2}\right]-\mathrm{NaX}$ nanocomposites are shown in Table 1. The $\mathrm{Si} / \mathrm{Al}$ molar ratio in $\mathrm{NaX}$ is 1.22 which is in agreement with the unit cell formula $\left(\mathrm{Na}_{88} \mathrm{Al}_{88} \mathrm{Si}_{104} \mathrm{O}_{384}\right)$ [42]. The Si/Al ratio remained unchanged in $\mathrm{M}$ (II)-NaX, indicating no occurrence of dealumination during the ion exchange. The $\mathrm{M} / \mathrm{N}$ molar ratio in $\mathrm{M}$-pydc-NaX shows only a slight distortion comparison with the free complex), which confirmed that the structure of the complex in the zeolite channels did not change. The contents of $\mathrm{M}, \mathrm{C}, \mathrm{H}$, and $\mathrm{N}$ metal to ligand ratio of about 1: 2 for [M(pydcH $\left.)_{2}\right]-\mathrm{NaX}$. However, slightly lower molar ratios in each case show a small trace of free metal ions in the lattice. 
Table 1

Analytical data for $\mathrm{NaX}, \mathrm{M}(\mathrm{II})-\mathrm{NaX}$ and $\left[\mathrm{M}(\mathrm{pydcH})_{2}\right]-\mathrm{NaX} ; \mathrm{M}=\mathrm{Co}, \mathrm{Ni}$

\begin{tabular}{|lllllllll|}
\hline Compound & $\% M$ & $\% \mathrm{C}$ & $\% \mathrm{~N}$ & $\% \mathrm{Si}$ & $\% \mathrm{Al}$ & $\% \mathrm{Na}$ & $\mathrm{M} / \mathrm{N}$ & $\mathrm{Si} / \mathrm{Al}$ \\
\hline $\mathrm{NaX}$ & - & - & - & 20.56 & 16.84 & 16.92 & - & 1.22 \\
\hline $\mathrm{Co}-\mathrm{NaX}$ & 5.20 & - & - & 20.36 & 16.72 & 12.25 & - & 1.22 \\
\hline [Co(pydcH) $\left.)_{2}\right]-\mathrm{NaX}$ & 3.84 & 10.58 & 1.78 & 20.13 & 16.47 & 14.01 & 0.51 & 1.22 \\
\hline $\mathrm{Ni}-\mathrm{NaX}$ & 4.32 & - & - & 20.72 & 16.93 & 13.53 & - & 1.22 \\
\hline$\left[\mathrm{Ni}(\mathrm{pydcH})_{2}\right]-\mathrm{NaX}$ & 3.23 & 8.74 & 1.46 & 19.33 & 15.81 & 14.87 & 0.52 & 1.22 \\
\hline
\end{tabular}

According to the $\mathrm{Si} / \mathrm{Al}$ ratio in $\mathrm{M}$ (II)-NaX remains unchanged indicating the absence of dealumination during ion exchange. It also confirms that the structure of zeolite channels has not changed after ion exchange and complex formation in cavities. The values of $\mathrm{M}, \mathrm{C}, \mathrm{H}, \mathrm{N}$ indicate the metal to ligand ratio of about 1: 2 for [M (pydcH) 2] -NaX.

\subsection{3 powder $\mathrm{X}$-ray diffraction}

The XRD pattern of $\mathrm{NaX}, \mathrm{M}(\mathrm{II})$ exchanged zeolite-X, and $\left(\left[\mathrm{M}(\mathrm{pydcH})_{2}\right]-\mathrm{NaX}\right)$ were obtained at $2 \theta=0^{\circ}-70^{\circ}$ are shown in Fig. 2. The crystal phases of the synthesized material can be determined by comparing the X-ray diffraction pattern and the ASTM cards. As shown in the figure, the XRD pattern of the Zeolite X is the same as the standard zeolite-X [36]. The absence of additional peaks in the XRD pattern indicates the synthesis of high purity zeolite-X. According to figure 2 , a little displacement in the peaks of the complexes indicate that the process of catalyst synthesis (ion exchange and encapsulation of the complexes) based on zeolite has caused minor changes in the distance of its crystal planes, but in general, the structure and zeolite framework of $\mathrm{NaX}$ remain stable during the preparation process of composites

\subsubsection{Scanning /Transmission electron microscopy}

Scanning electron microscopy (SEM) Images of $\mathrm{NaX}$ and $\left.\left[\mathrm{M}(\mathrm{pydcH})_{2}\right)\right]-\mathrm{NaX}$ is shown in Figure 3 . The sample particles have an irregularly shaped angle, an almost smooth surface, and multilayer sheets. These images show that the exchanged ions and complexation are mostly inside the pores of the zeolite $\mathrm{X}$.

TEM images of $\mathrm{NaX}$ and $\left[\mathrm{M}(\mathrm{pydcH})_{2}\right]-\mathrm{NaX}$ are shown in Figure 4 . These pictures show that the structure of all of them is rectangular cubic. The $\left[\mathrm{Ni}(\mathrm{pydcH})_{2}\right]-\mathrm{NaX}$ and $\left[\mathrm{Co}(\mathrm{pydcH})_{2}\right]-\mathrm{NaX}$ also show slightly opaque and regular form but a little change at the surface margin. In addition, partial aggregation is considered compared to the parent zeolite. Due to the encapsulation of complex sections in zeolite channels, the morphology of $\left[\mathrm{Ni}(\mathrm{pydcH})_{2}\right]-\mathrm{NaX}$ and $\left[\mathrm{Co}(\mathrm{pydcH})_{2}\right]-\mathrm{NaX}$ show a crystalline nature. Images of $\left[\mathrm{Ni}(\mathrm{pydcH})_{2}\right]-\mathrm{NaX}$ and $\left[\mathrm{Co}(\mathrm{pydcH})_{2}\right]-\mathrm{NaX}$ show the absence of $\mathrm{M}(\mathrm{II})$ complex traces on the surface.

\subsection{Catalytic activity (Oxidation of atenolol)}


The catalytic activity of $\left[\mathrm{Ni}(\mathrm{pydcH})_{2}\right]-\mathrm{NaX}$ and $\left[\mathrm{Co}(\mathrm{pydcH})_{2}\right]-\mathrm{NaX}$ composites in the degradation oxidation reaction of a solution of atenolol $(10 \mathrm{ml}, 20 \mathrm{ppm})$ in the presence of $\mathrm{H}_{2} \mathrm{O}_{2}$ were investigated. Process optimization was performed by the change of different parameters such as reaction time $(30,60,90,120$, and 180 minutes), the amount of catalyst $(5,10,15,20,25 \mathrm{mg})$, and the volume of hydrogen peroxide (1, 2 and $3 \mathrm{ml}$ ) at $30^{\circ} \mathrm{C}$ under conditions where all other factors were constant (Table 2). 
Table 2

Effect of various parameters on the catalytic oxidative degradation of atenolol

\begin{tabular}{|c|c|c|c|c|}
\hline Catalyst & Time (min) & Catalyst (mg) & $\mathrm{H}_{2} \mathrm{O}_{2}(\mathrm{~mL})$ & Degradation (\%) \\
\hline \multirow[t]{14}{*}[\mathrm{Co}(\mathrm{pydcH})_{2}]{$-\mathrm{NaX}$} & 30 & 5 & 1 & 28.2 \\
\hline & 60 & 5 & 1 & 55.1 \\
\hline & 90 & 5 & 1 & 59.2 \\
\hline & 120 & 5 & 1 & 59.8 \\
\hline & 180 & 5 & 1 & 60.1 \\
\hline & 60 & 5 & 1 & 55.1 \\
\hline & 60 & 10 & 1 & 75.6 \\
\hline & 60 & 15 & 1 & 75.9 \\
\hline & 60 & 20 & 1 & 74.3 \\
\hline & 60 & 25 & 1 & 71.2 \\
\hline & 60 & 10 & 1 & 75.6 \\
\hline & 60 & 10 & 2 & 79.8 \\
\hline & 60 & 10 & 3 & 81.2 \\
\hline & 60 & 10 & 4 & 82.3 \\
\hline \multirow[t]{12}{*}[\mathrm{Ni}(\mathrm{pydcH})_{2}]{$-\mathrm{NaX}$} & 30 & 5 & 1 & 23.6 \\
\hline & 60 & 5 & 1 & 48.3 \\
\hline & 90 & 5 & 1 & 51.7 \\
\hline & 120 & 5 & 1 & 52.3 \\
\hline & 180 & 5 & 1 & 52.8 \\
\hline & 60 & 5 & 1 & 48.3 \\
\hline & 60 & 10 & 1 & 59.8 \\
\hline & 60 & 15 & 1 & 60.1 \\
\hline & 60 & 20 & 1 & 57.9 \\
\hline & 60 & 25 & 1 & 53.6 \\
\hline & 60 & 10 & 1 & 59.8 \\
\hline & 60 & 10 & 2 & 67.3 \\
\hline
\end{tabular}




\begin{tabular}{|lllll|}
\hline Catalyst & Time $(\mathrm{min})$ & Catalyst $(\mathrm{mg})$ & $\mathrm{H}_{2} \mathrm{O}_{2}(\mathrm{~mL})$ & Degradation $(\%)$ \\
\hline 60 & 10 & $\mathbf{3}$ & 70.4 \\
& 60 & 10 & 4 & 71.1 \\
\hline
\end{tabular}

The concentration of residual atenolol was calculated using a spectrophotometer at a wavelength of 250$700 \mathrm{~nm}$ according to the following equation:

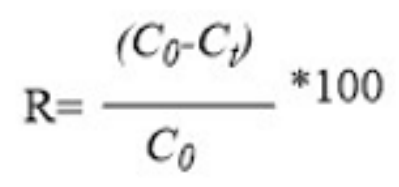

Where $\mathrm{C}_{0}$ and $\mathrm{C}_{\mathrm{t}}$ indicate the initial and final

concentration of the atenolol (after the degradation process), respectively.

The results showed that the oxidative degradation of atenolol increased with enhancement time. Since there was a slight increase in efficiency after 60 minutes, the optimize time was considered 60 minutes.

To find the optimal amount of catalyst, atenolol degradation was performed in different amounts of catalyst from 5 to $25 \mathrm{mg}$. oxidation efficiency of $\% 60.8$ and $75.9 \%$ is obtained after 60 minutes of reaction at $30^{\circ} \mathrm{C}$ with $10 \mathrm{mg}$ of catalyst in the presence of $\left[\mathrm{Ni}(\mathrm{pydcH})_{2}\right]-\mathrm{NaX}$ and $\left[\mathrm{Co}(\mathrm{pydcH})_{2}\right]-\mathrm{NaX}$, respectively (Table 2). The degradation of atenolol becomes greater with increasing the amount of catalyst up to $15 \mathrm{mg}$, but an additional increase in the amount of catalyst reduces the oxidation performance of atenolol due to lower access to active sites. In addition, excess catalyst leads to the decomposition of $\mathrm{H}_{2} \mathrm{O}_{2}$, which ultimately prevents the oxidative degradation reaction [43].

Homogeneous complex compounds are not recyclable as a catalyst even once and lose their catalytic activity after use. However, heterogeneous catalysts can be reused after catalytic filtration and washing without major damage to catalytic activity [44]. After completion of the reaction, filtration and separation of the catalyst, and then washing with a solvent, the catalyst was reused under similar conditions. The atomic absorption spectroscopy of catalysts did not show any loss of nickel or cobalt after reuse, although their catalytic activity was slightly reduced.

\section{Conclusion}

The aim of this study was to remove atenolol from aqueous solutions using the oxidative degradation reaction in the presence of $\left[\mathrm{Co}(\mathrm{pydcH})_{2}\right]-\mathrm{NaX}$ and $\left[\mathrm{Ni}(\mathrm{pydcH})_{2}\right]-\mathrm{NaX}$ nanocomposites as a catalyst. The results showed that the catalysts were synthesized correctly and the cobalt complex with pyridine-2,6dicarboxylic acid was encapsulated to a greater extent than the nickel complex in the zeolite $X$ cavities. According to the molar ratio of metal to nitrogen, it can be concluded that the molar ratio of metal to the ligand is 1:2. The catalytic degradation of atenolol shows that [Co(pydcH $\left.)_{2}\right]-\mathrm{NaX}$ nanocomposite has more activity than $\left[\mathrm{Ni}(\mathrm{pydcH})_{2}\right]-\mathrm{NaX}$, due to the amount of complex encapsulation in the zeolite $\mathrm{X}$ 
cavities. Degradation of atenolol increases with enhancement temperature, time, and amount of hydrogen peroxide in the presence of both complexes. Although the oxidation percentage of atenolol increases in the presence of catalyst up to $10 \mathrm{mg}$, but the percentage of oxidation of atenolol decreases by the excess amount of catalyst because of the decomposition of $\mathrm{H}_{2} \mathrm{O}_{2}$. In addition, the removal efficiency of atenolol showed a reduction of less than $10 \%$ in the reuse of catalysts for three periods.

\section{Declarations}

\section{Acknowledgments}

The authors appreciate the financial support of the Islamic Azad University, Yazd branch in the implementation of the project.

\section{References}

1. N. Bolong, A.F. Ismail, M.R. Salim, T. Matsuura, Desalination 239(1-3), 229-246 (2009)

2. H.B. Quesada, A.T.A. Baptista, L.F. Cusioli, D. Seibert, C.O. Bezerra, R. Bergamasco, Chemosphere 222, 766-780 (2019)

3. J.O. Tijani, O.O. Fatoba, L.F. Petrik, Water Air Soil Pollut. 224)11), 1770 (2013)

4. C. Teodosiu, A.F. Gilca, G. Barjoveanu, S. Fiore, J. Clean. Prod. 197(1), 1210-1221 (2018)

5. Q. Liao, H. Rong, M. Zhao, H. Luo, Z. Chu, R. Wang, Sci. Total Environ. SCI Total Environ, 757, 143981 (2021)

6. J. Luo, Q. Zhang, J. Zhao, Y. Wu, L. Wu, H. Lia, M. Tang, Y. Sun, W. Guo, Qian Feng, J. Cao, D. Wang, J. Hazard. Mater. 383, 121176 (2020)

7. X. Huang, Q. Xu, Y. Wu, D. Wang, Q. Yang, F. Chen, Y. Wu, Z. Pi, Z. Chen, X. Li, Q. Zhong, Bioresour. Technol. 298, 121598 (2019)

8. E. Proschak, H. Stark, D. Merk, J. Med. Chem. 62(2), 420-444 (2019)

9. U. Anand, N. Jacobo-Herrera, A. Altemimi, N. Lakhssassi, Metabolites 9(11), 258 (2019)

10. D. Tungmunnithum, A. Thongboonyou, A. Pholboon, A. Yangsabai, Medicines 5(3), 93 (2018)

11. S. Rastogi, M.M. Pandey, A.K.S. Rawat, Phytomedicine 23(11), 1082-1089 (2016)

12. H.T. Ong, BMJ. 334(7600), 946-949 (2007)

13. G. Jobin, A. Cortot, J. Godbillon, M. Duval, J.P. Schoeller, J. Hirtz, J.J. Bernier, Br. J. clin. Pharmac. 19, 97S-105S (1985)

14. M.L. Farre, S. Perez, L. Kantiani, D. Barcelo, Trends Analyt. Chem. 27(11), 991-1008 (2008)

15. D. Simazaki, R. Kubota, T. Suzuki, M. Akiba, T. Nishimura, S. Kunikane, water res. 76, 187-200 (2015)

16. B. Dehdashti, M.M. Amin, H.R. Pourzamani, L. Rafati, M. Mokhtari, Water Sci. Technol. 3, 636-649 (2017) 
17. E.S.M. Mouele, J.O. Tijani, K.O. Badmus, O. Pereao, O. Babajide, C. Zhang, T. Shao, E. Sosnin, V. Tarasenko, O.O. Fatoba, K. Laatikainen, L.F. Petrik, Int. J. Environ. Res. Public Health 18(4), 1683 (2021)

18. J.L. Sotelo, G. Ovejero, A. Rodríguez, S. Alvarez, J. García, Ind. Eng. Chem. Res. 51(13), 5045-5055 (2012)

19. G.D. Norcom, R.I. Dodd, Am. Water Works Assoc. 22(11), 1414-1437 (1930)

20. V. Homem, L. Santo, J. Environ. Manage. 92(10), 2304-2347 (2011)

21. C. Plüss-Suard, A. Pannatierb, A. Kronenberg, K. Mühlemann, G. Zanetti, J. Hosp. Infect. 79(2), 166$171(2011)$

22. S. Rajagopal, J. C. Kuriacose, Curr. Sci. 50(24), 1047-1052 (1981)

23. J. Malinowski, D. Zych, D. Jacewicz, B. Gawdzik, J. Drzezdzon, Int. J. Mol. Sci. 21(15), 5443 (2020)

24. M.A. Andrade, A.S. Mestre, A.P. Carvalho, A.J.L. Pombeiro, L. M.D.R.S. Martin, Catal. Today 357, 46$55(2020)$

25. P. Kalck, M. Urrutigoïty, Chem. Rev. 118(7), 3833-3861 (2018)

26. H. Nasrallah, J.C. Hierso, Chem. Mater. 31(3), 619-642 (2019)

27. S.A. Dergunov, A.T. Khabiyev, S.N. Shmakov, M.D. Kim, N. Ehterami, M.C. Weiss, V.B. Birman,

E. Pinkhassik, ACS Nano 10(12), 11397-11406 (2016)

28. E. Gross, F.D. Toste, G.A. Somorjai, Catal. Lett. 145, 126-138 (2015)

29. T. Derbe, S. Temesgen, M. Bitew, Adv. Mater. Sci. Eng. 6637898 (2021)

30. S. Golbad, P. Khoshnoud,.G. Keleney, N. Abu-Aahra, Water Environ. J. 34(3), 342-349 (2020)

31. L. Chen, Q. Xu, Matter 1(1), 57-89 (2019)

32. N. Kosinov, C. Liu, E.J.M. Hensen, E.A. Pidko, Chem. Mater. 30(10), 3177-3198 (2018)

33. K.J. Balkus,, G.G. Alexei, J. Incl. Phenom. Macrocycl. Chem. 21, 159-184 (1995)

34. C. Li, Catal. Rev. - Sci. Eng. 46(3-4), 419-492 (2004)

35. K.J. Balkus, K.T. Ly, J. Chem. Edu. 68(10), 875-877 (1991)

36. C.K. Modi, P.M. Trivedi, Adv. Mater. Lett. 3(2), 149-153 (2012)

37. M. Davidova, D. Nachtigallova, R. Bulanek, P. Nachtigall, J. Phys. Chem. B 107(10), 2327-2332 (2003)

38. R. Ferreira, M. Silva, C. Freire, B. de Castro, J.L. Figueiredo, Microporous Mesoporous Mater. 38(23), 391-401 (2000)

39. Y. Huang, Z. Jiang, W. Schwieger, Chem. Mater. 11(5), 1210-1217 (1999)

40. M.R. Maurya, A.K. Chandrakar, S. Chand, J. Mol. Catal. A Chem. 263(1-2), 227-237 (2007)

41. S.A. Chavan, D. Srinivas, P. Ratnasamy, Chem. Commun. 12, 1124-1125 (2001)

42. H.S. Abbo, S.J. Titinchi, Top Catal. 53(19-20), 1401-1410 (2010)

43. R. Dittmeyer, J.D. Grunwaldt, A. Pashkova, Catalysis Today 248, 149-159 (2015) 
Figures

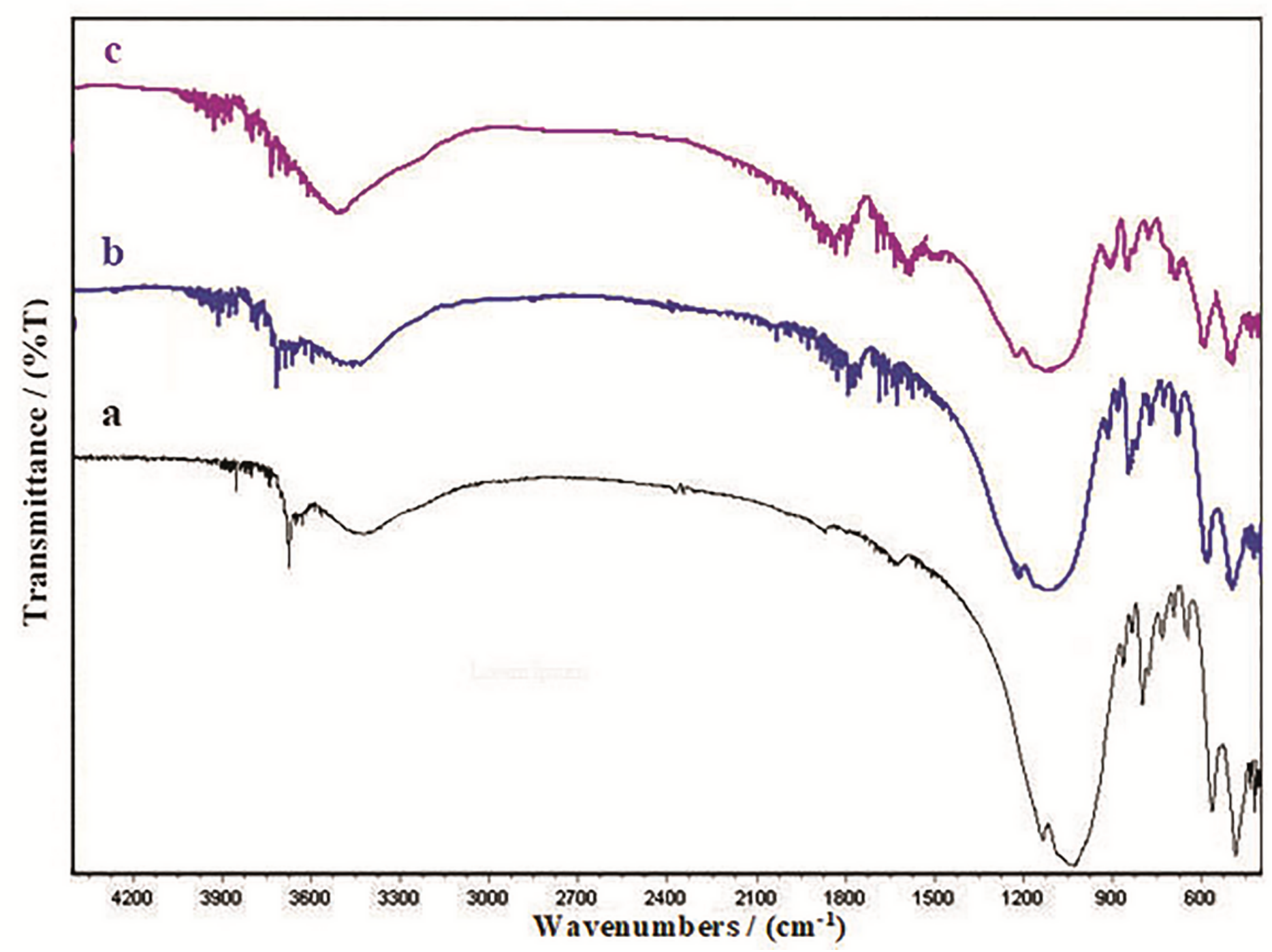

Figure 1

FTIR spectra of (a) $\mathrm{NaX}$, (b) [Co(pydcH) $\left.)_{2}\right]-\mathrm{NaX}$ and (c) [ $\left.\mathrm{Ni}(\mathrm{pydcH})_{2}\right]-\mathrm{NaX}$ 


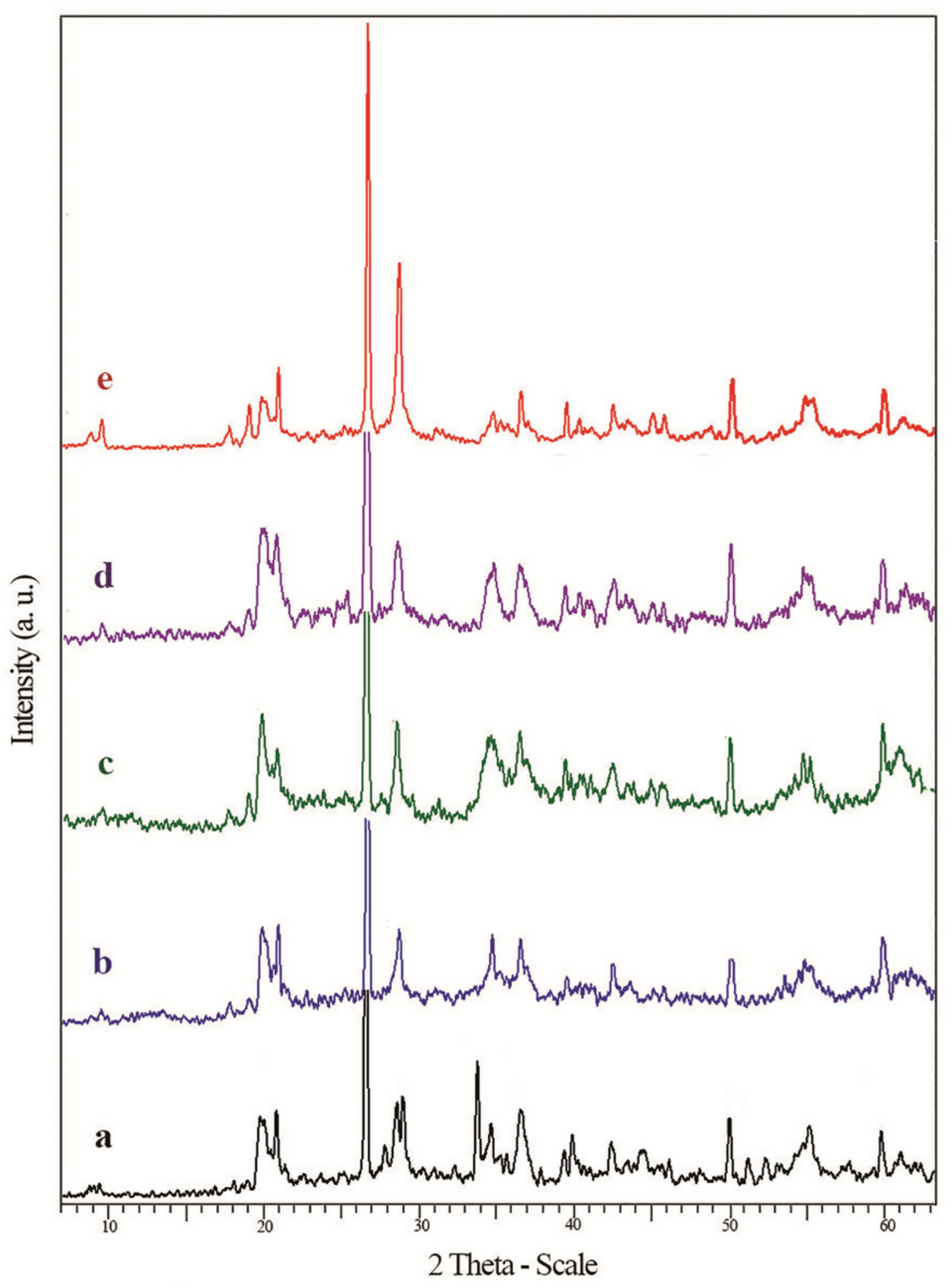

Figure 2

XRD patterns of (a) NaX, (b) Co-X, (c) Ni-X, (d) [Co(pydcH) $\left.)_{2}\right]-\mathrm{NaX}$ and (e) [Ni(pydcH) $\left.{ }_{2}\right]-\mathrm{NaX}$ 

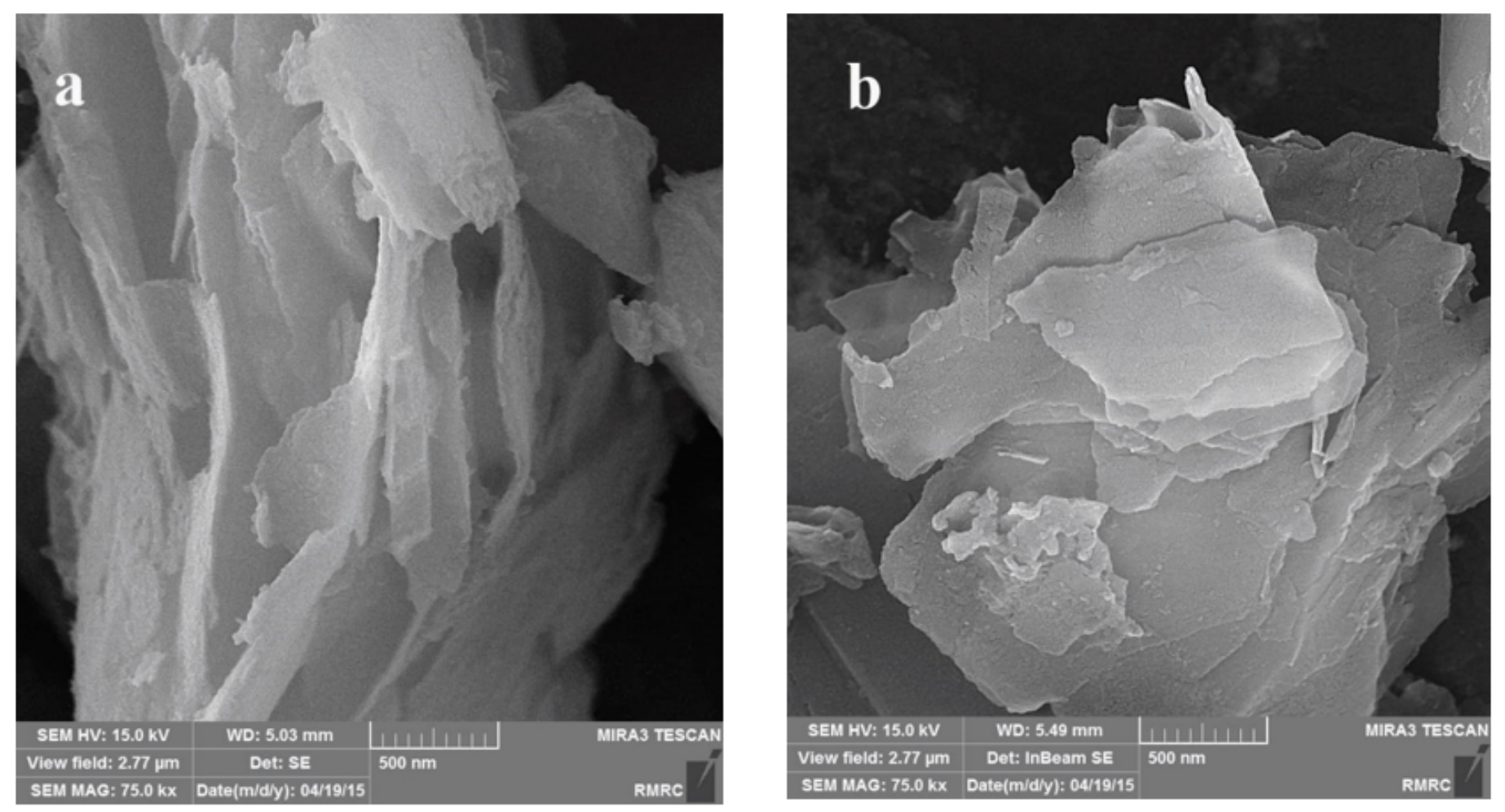

\section{Figure 3}

SEM images of the (a) $\mathrm{NaX}$, (b) $\left[\mathrm{Co}(\mathrm{pydcH})_{2}\right]-\mathrm{NaX}$ and (c) $\left[\mathrm{Ni}(\mathrm{pydcH})_{2}\right]-\mathrm{NaX}$
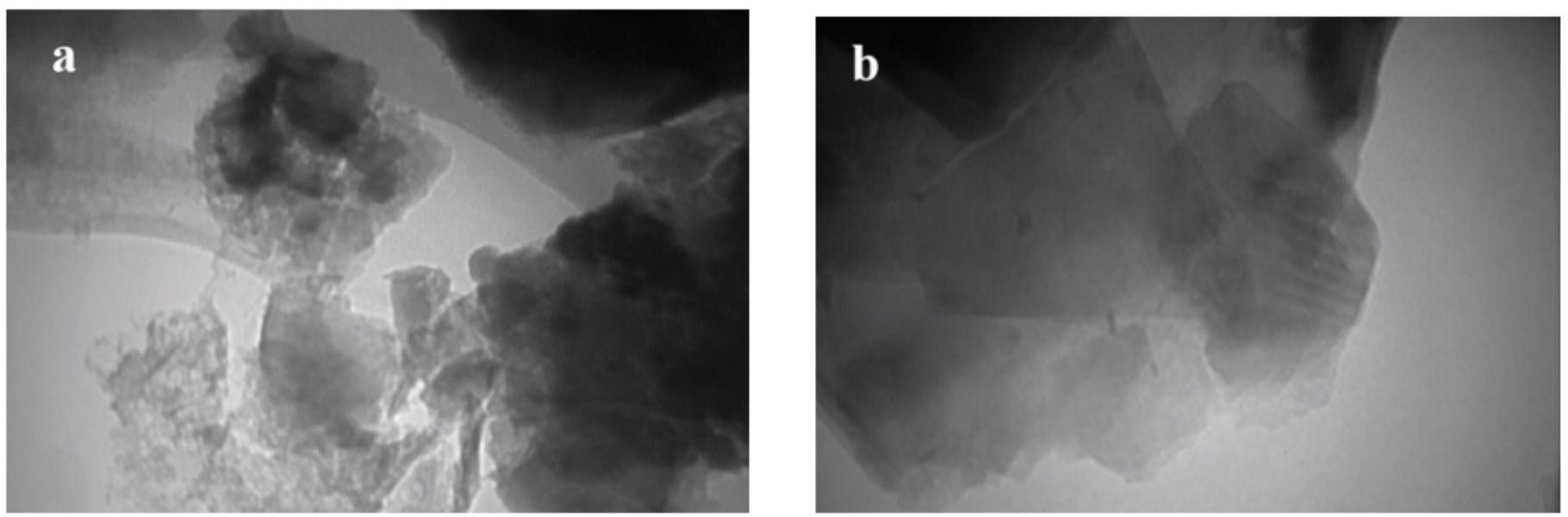

Figure 4

TEM images of the (a) $\mathrm{NaX}$, (b) $\left[\mathrm{Co}(\mathrm{pydcH})_{2}\right]-\mathrm{NaX}$ and (c) $\left[\mathrm{Ni}(\mathrm{pydcH})_{2}\right]-\mathrm{NaX}$ 